\title{
Światto w zabytkowej architekturze mieszkaniowej Krakowa
} Light in historic residential architecture "ก ช

\begin{abstract}
Streszczenie
Artykuł przybliża problematykę współczesnych aranżacji konserwatorskich w zabytkowym budownictwie mieszkaniowym. Światło w kontekście budynków zabytkowych stanowi rozległą tematykę, którą można podzielić na dwie grupy. Pierwszą z nich jest światło dzienne, drugą światło sztuczne. Zarówno światło pochodzenia naturalnego - dzienne, jak i pochodzenia antropogenicznego - sztuczne, można rozpatrywać w kontekście wnętrza oraz zewnętrza budynku. Na przykładzie wybranych dziewięciu obiektów zlokalizowanych w Krakowie zilustrowano współczesne rozwiązania dotyczące światła z uwzględnieniem wyżej wskazanego podziału.
\end{abstract}

\begin{abstract}
The article addresses the issue of contemporary arrangement of restoration in historic housing. Light in the context of historic buildings is a vast subject, which can be divided into two groups. The first of these is day light, the second is artificial light. Both, light of natural origin - day light, and anthropogenic origin- artificial light, can be analyzed in the context of the interior and exterior of the building. In the example, we have selected nine properties located in Cracow which illustrate contemporary light solutions taking into account the above indicated division.
\end{abstract}

Słowa kluczowe: historyczna zabudowa, słońce, iluminacja, aranżacja konserwatorska Keywords: historic buildings, sun light, illumination, arrangement of conservation work

\section{Wstęp}

światło, w szerokim pojęciu, jest jednym z parametrów określających cechy zabudowy. Może być postrzegane przez pryzmat zarówno elewacji, kontekstu urbanistycznego, jak i wnętrza. Oświetlenie pochodzenia naturalnego jest uzależnione od różnych czynników, takich jak pora roku, szerokość geograficzna, warunki atmosferyczne czy też pora dnia ${ }^{1}$. Ze względu na relatywnie ograniczone możliwości wykorzystania światła słonecznego do oświetlenia budynków, od wieków stosowano różne metody rozjaśnienia przestrzeni mieszkalnych, począwszy od płomieni ognia, lamp gazowych i naftowych, po współczesne elektryczne oprawy oświetleniowe. Powyższe zagadnienie opisane zostało w publikacji Mirosława Sulmy i Marii Katarzyny Kaczorowskiej Czas na teorię?, która ukazała się w 2003 roku. Głównym problemem iluminacji zabudowy zabytkowej jest zachowanie odpowiedniej proporcji pomiędzy naturalnym światłem, względem którego dany budynek został ukształtowany, a oświetleniem sztucznym, które jest stosunkowo obcym elementem.

\section{Współczesne uwarunkowania prawne}

Istniejące przepisy prawne określają precyzyjnie proporcje jakie powinny posiadać projektowane elementy zabudowy, aby zapewnić im odpowiednie oświetlenie dzienne. Zarówno

\section{Intro}

Light in a broad sense, is one of the parameters that define the characteristics of a building. This can be seen through the prism of facades, urban context, as well as the building's Interior. Natural lighting is dependent on various factors, such as season, latitude, weather conditions or time of a day'. Due to the relatively limited use of sunlight to illuminate buildings, over the centuries various methods have been used for lighting space, starting with the flames of fire, gas lamps and oil, after that modern lighting fixtures. This issue is described in the publication by Mirosława Sulmy and Maria Katarzyna Kaczorowska Time for a theory? which appeared in 2003. The main problem of illumination historic buildings is maintaining the appropriate proportions between natural light, relative to the one the given building was constructed by, and artificial lighting, which is relatively a foreign element.

\section{Contemporary legal conditions}

Existing legal provisions specify the precise proportions in which buildings should be designed, to provide them with adequate natural lighting. Both the proportions between the windows (minimum 
proporcje pomiędzy powierzchnią okien (minimum 1:8 i 1:12, liczona w nasłonecznienia (3 godziny $w$ godzinach 7.00-17.00 $\mathrm{w}$ pokojach mieszkalnych i 1,5 godziny w mieszkaniach wielopokojowych, przy czym nie dotyczy to mieszkań jednopokojowych)2 Analizę poszczególnych zapisów ustaw oraz przepisów można również odnaleźć w artykule Małgorzaty Bartnickiej z 2010 roku „Wczoraj, dziś $\mathrm{i}$ jutro w promieniach słonecznych (?)" (sic!!). Ze wzgledu na złożoność problematyki projektowania (sic!). Ze wzgędu na zlożonośc problematyki projektowania budynkow wa slonecz 2012 roku nego $w$ budynkach" że zác ze zarowno przepisy prawne jak i narzędzia projektowe opisane w powyiszych publikacach maja zastosowanie przede wszystkin w now powstającym budownictwie. W odniesieniu do budy wow pows zacy zastosowania niniejszych zasad.

\section{Oświetlenie naturalne wnętrz}

W budynkach historycznych, inaczej niż obecnie, ksztattowano układ wnętrz. Pomieszczenia dzienne, sypialnie oraz kuchnie często były bezpośrednio połączone tworząc układ amfiladowy. Proporcje wysokości kondygnacji oraz głębokości wnętrz były inne niż we współcześnie projektowanych obiektach. Ponadto proporcje otworów okiennych do kubatury pomieszczen przeważnie są mniejsze niż w obecnie wznoszonych budynkach. Niniejsze cechy zabytków determinują szereg nowoczesnych rozwiązań, które mają na celu zwiększanie ilości światta słonecznego docierajacego do środka.

Jednym ze sposobów doświetlenia wnętrz jest zwiększenie płaszczyzny przepuszczającej promienie światta naturalnego poprzez wymiane stolarki okiennej ze skrzynkowej na jednoramowa. Stolarka skrzynkowa, w porównaniu z jednoramowa przepuszcza znacznie mniej światta naturalnego do wnetrza, ze wzgledu na podwóiny zestaw skrzydeł okiennych, który dodatkowo posiada w zewnetrznych kwaterach profile, szczebliny oraz nod́wieth, o mniejszych przekrojach niż analogiczne w wyrazie plastyczn o a znich

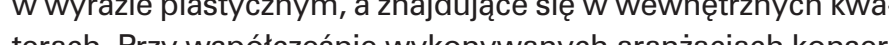

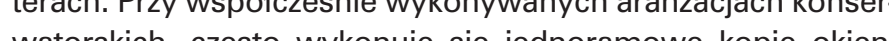

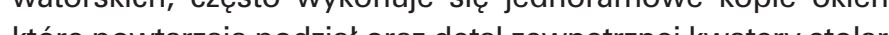

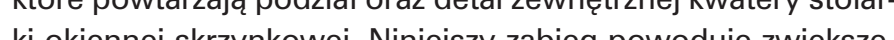
ki okiennej skrzylowej. Niniejszy zabieg powoduje zwiększenie powierzchni przepuszzzalnego szkla. Przykładami wykorzystania powyzejopisanej metody sa: narożna kamienica przy ul. Ambrożego Grabowskiego 2/ ul. Karmelickiej 52 (il. 1 i 2) oraz kamienicy przy ul. Karmelickiej 11 (il. 3).

Historyczne obiekty posiadają liczne nawarstwienia świadczące o ich przemianach architektonicznych, niejednokrotnie wskazują one na zmiany funkcji. Przez łączenie budynków, zmianę przeznaczenia, funkcji np. z sakralnej na mieszkaniową, wykonywano adaptację pomieszczen do owczesnych wymogów. Współczesnie wykonuje się również aranżacje konserwatorskie mające na celu mozliwe dostosowanie do współczesnych oczekiwań wyżej wymienionych przestrzeni. Przykładem takiej aranżacji, która została wykonana w latach 2014-2016 jest zespół mieszkaniowy „Pod Wawelem”. Opracowania pro-
$1: 8$ and $1: 12$ calculated in the light of the frames) 7 to 17 in residential rooms and 1.5 hours in the multi- rooms, and this does not include the oneroom apartments's. Analysis of individual records sets and rules can also be found in the article by Malgorzata Bartnicka from 2010 "Wczoraj, dziś jutro w promieniach stonecznych (?)" (sic!).

Due to the complexity of the issue of designing of tools are used which are described in 2012 “ sign tools daylight in buildings" by Zbigniew Turle. Keep in mind, however that both legislation and the design tools that are described in the above publications are mainly applied in the newly emerging construction. With regard to historic buildings it is not always possible to apply these rules.

3. Natural interior lighting

In historic buildings, as opposed to today, the layout of the interior was designed. Living rooms, bedrooms and kitchens were often directly connected to form a pass through room system. The heigh of the storey and depth of the interior were different from those of buildings designed today. In addition, the proportions of the window openings to the cubic capacity of the rooms are generally lower than in the currently erected buildings. These characteristics of historic buildings determine a numamount of sunlight reaching the building's center. One way of increasing interior lighting is to increas the field of natural light through the replacement of window frames from box to single. In comparison to single bed, the box frame allows much less natyral lights into the interior, due to the double set of window wings, which additionally has profiles with smaller cross-sections than their plastic analogues and located in the inner quarters. At present these arrangements are preserved, though often, onesided copies of windows are made, which repeat the division and detail of the exterior of the box carpentry window. This treatment increases the surface of the permeable glass. Examples of the use of the above described method are: the corne tenement at Ambrożego Grabowskiego 2 street Karmelicka 52 street (Fig. no. 1 and 2), and tenement house at Karmelicka 11 street (Fig. no. 3). Historical objects have many layers of evidence of their archlectural changes, and they often point changing the designation, functions, from eg Sacr to housing an adaptation of the premises to the quirements was made. Contemporary preservation arrangements are also being made to adapt to the contemporary expectations of the aforementioned space. An example of such arrangement, which was made in the years 2014-2016 is the housing complex "Pod Wawelem". Design work was done by a Design Office from Cracow. A complex of three buildings linked together made up the complex that through historical transformations, possessed in its

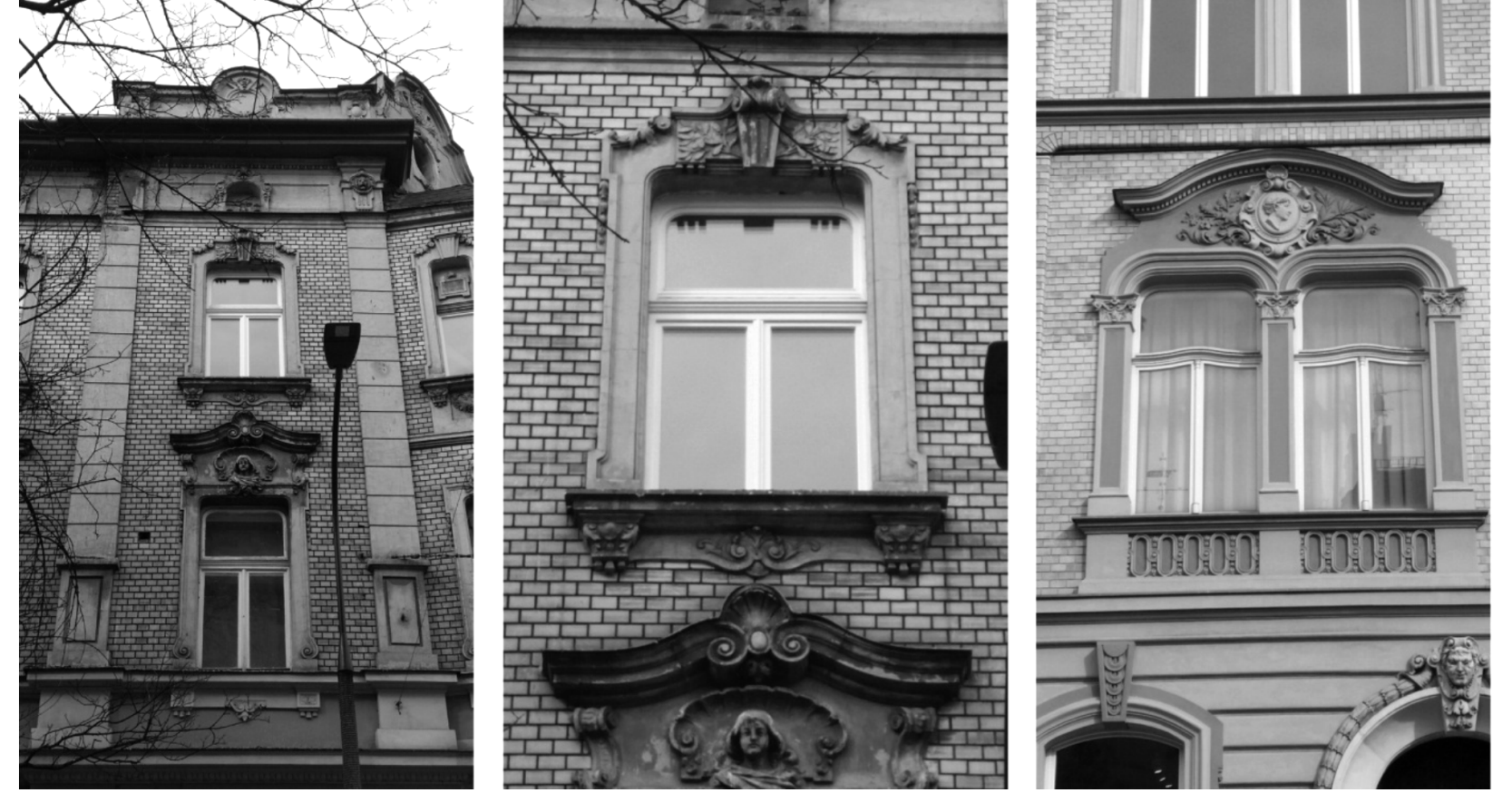

II. 1 po lewej, il. 2 w ́środku, stolarka okienna wymieniona na wspótcześnie wykonane kopie stolarki historycznej w budynku przy ul. Ambroże-
go Grabowskiego $2 /$ ul. Karmelickiej 52 oraz il. 3 po prawej, wymieniona współcześnnie stolarka okienna w kamienicy przy ul. Karmelickiej 11 illl 1 on the left, ill. 2 in the middle, window frames listed as the contemporary copies of historical joinery in the building at Ambroiego Grabow-
skiego 2 Street / Karmelicka 52 Street and ill 3 on the right shows the window frames in tenement house at Karmelicka 11 Street

jektowe wykonało Autorskie Biuro Projektowe z Krakowa. Zespół trzech budynków połączonych ze sobą tworzył kompleks, który poprzez przemiany historyczne posiadał $\mathrm{w}$ swojej strukturze dwie kaplice, nagrobną z XVIII w. oraz narożną, ośmioboczną, zaprojektowaną przez Karola Zarembę w XIX w.

Kaplica nagrobna zlokalizowana we wschodniej części wschodniego skrzydła kompleksu została wybudowana na planie prostokąta o bokach 7,20 m i 5,00 m oraz wysokości w najwyższych punktach 4,73 m. Pierwotnie posiadała niewielkie cztery okna skrzynkowe zlokalizowane $w$ górnych partiach północnej i południowej ściany. W późniejszych czasach wykonano w północnej ścianie dwa otwory drzwiowe, które stanowiły czasowe doświetlenie wnętrza. W trakcie prowadzonych prac modernizacyjnych obiektu właczono kaplice do jednego z powstałych apartamentów. W miejscu niehistorycznej stolarki drzwiowej wprowadzono przeszklone drzwi o historyzujacej formie które nie tylko doświetlity pomieszczenie, ale równiez podkréslity osiowe podziaty kolebkoweszkepieni z luneta

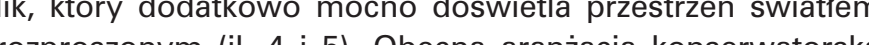
przestrzy w (il. 4 i 5). Obecna araziacja kons swatorka

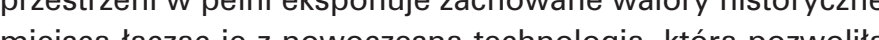
w tej przestrzeni wyeksponować jej atuty poprzez oświetlenie.

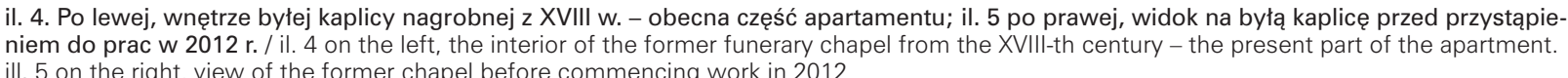

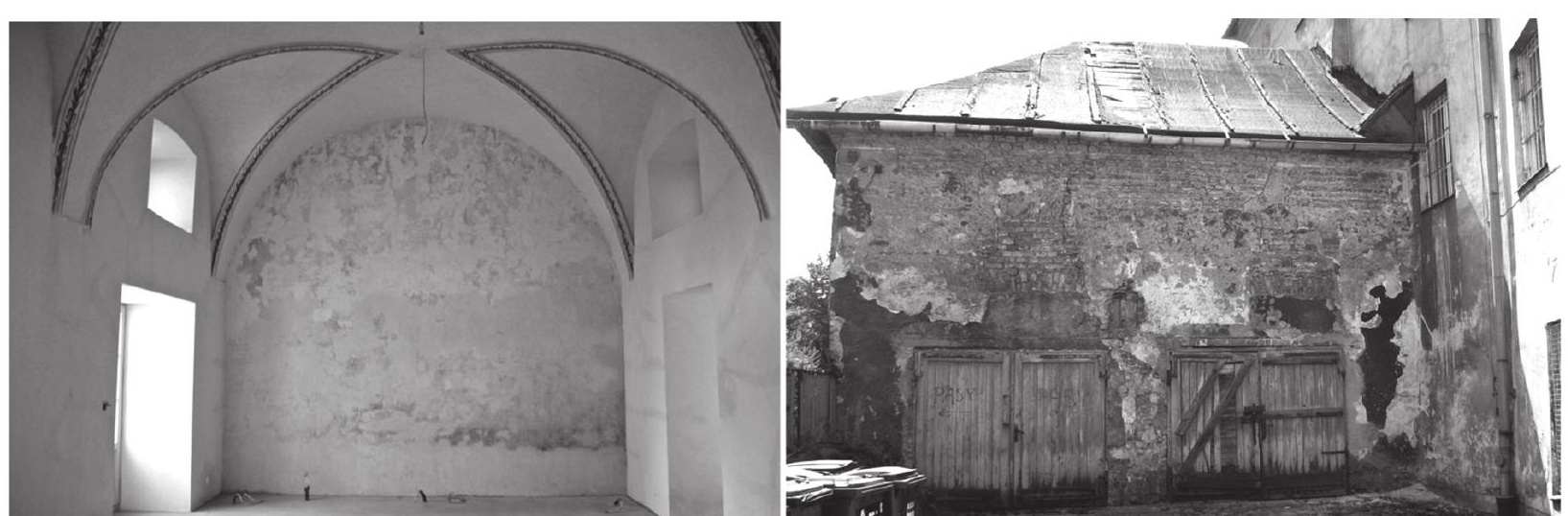

structure two chapels, a tombstone from the eighteenth century and an octagonal corner designed

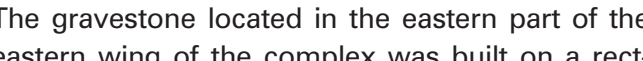
and had four small box windows located in the upper parts of the north and south walls. In later times, two doorways were made in the north wall, which were temporary lighting for the interior. During the renovation works, a chapel was included in one of the apartments. In the non- historic doors joinery, glass doors with a historic shape were introduced which not only illuminated the room, but also highighted the axial division of the vaulted celling with inetes. In addition, the place where the historic

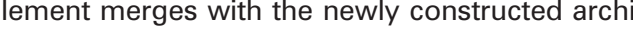

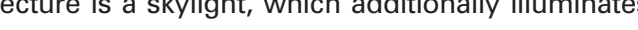
(Fig.no. 4 and 5). The exposes the present of the restoration area fully (a) allow for them with modern technology, which through lighting

Xerner of . a height at the highest points of $4,73 \mathrm{~m}$. Originally Koletek Street and Sukiennicza Street, after the de- 


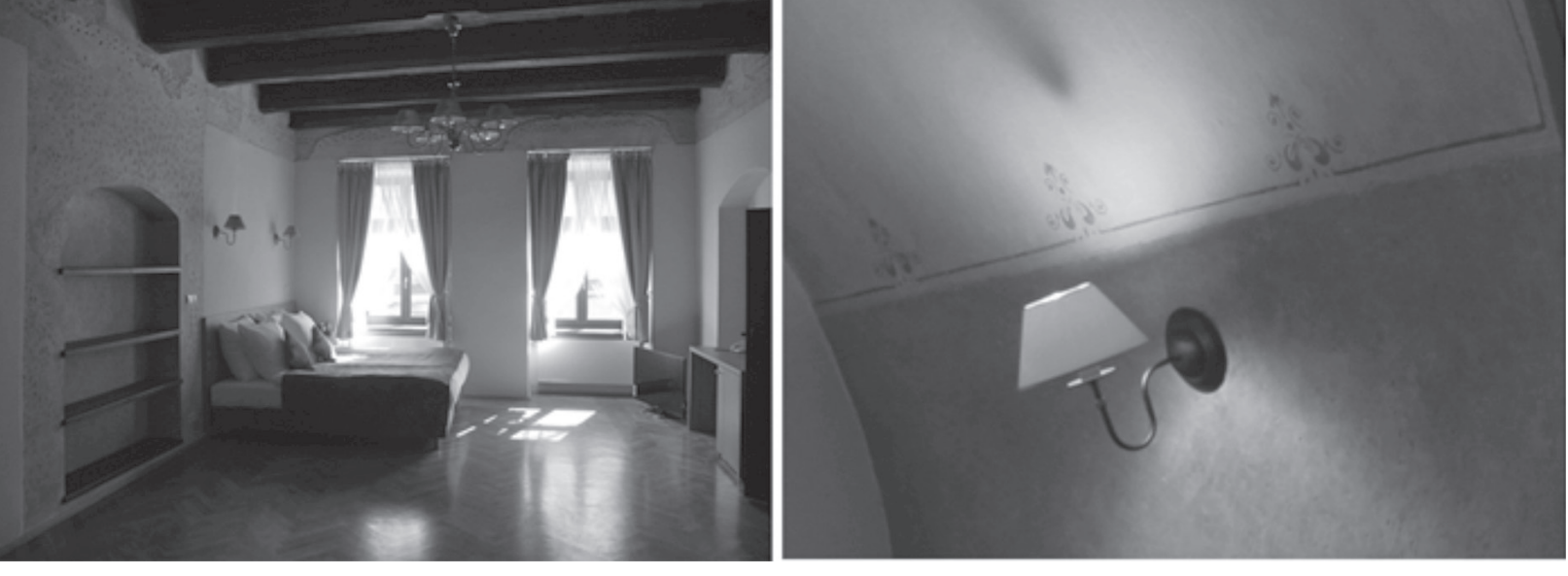

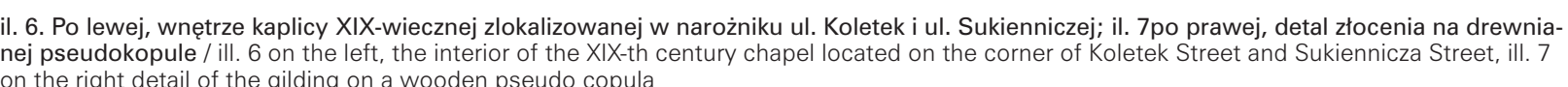

Kaplica XIX-wieczna, zlokalizowana w narożniku ul. Koletek i ul. Sukienniczej, po desakralizacji, od ok 1950 roku $^{3}$ pełnita funkcję sali gimnastycznej. Prywatny inwestor zaaranżował w tym miejscu "Apartament Królewski". Wnętrze sali o głębokości 12,17m i wysokości 11,24 m, zbudowano na planie ośmiobocznym. Pomieszczenie bogato dekoruje polichromia z przedstawieniami ornamentalnymi i figuralnymi $z$ lat 20. lub 30. XX wieku w ciemnych odcieniach ze złoceniami ${ }^{4}$. Pomieszczenie doświetla pięć witraży. Witraże ułożono naprzemiennie, trzy rozety o średnicy $1,4 \mathrm{~m}$ wypełnione szkłem barwionym oraz prostokątne, zakończone łukiem odcinkowym o wymiarach 2,47 m na 5,95 m, w górnej partii wypetnione szkłem barwionym, $w$ dolnej szkłem bezbarwnym. Ślusarka okienna zlokalizowana jest na ścianie $z$ absydą oraz na ścianach bocznych, okalających niegdyśs strefę sacrum. Cała kompozycja została przemyślana i zakomponowana tak, by podkreślać funkcję liturgiczna.

Pomimo relatywnie dużej powierzchni otworów okiennych pomieszczenie nadal sprawia wrażenie ciemnego, nieprzystosowanego do funkcji mieszkaniowej, lecz sakralnej (il. 6 i 7). Pierwotne przeznaczenie jest w tym miejscu silnie eksponowane również dzieki umiejetnemu operowaniu świttem przestrzeni gdzie niegdyś znajdowat sie ottarz, bija ośe ce łuny światta.

\section{Oświetlenie sztuczne wnętrz}

Oświetlenie wnetrz historycznych świattem sztucznym jest naturalnym procesem ksztaltowanym zarówno przez współczesnych projektantów, jak i użytkowników. Zazwyczaj im starszy budynek, tym więcej nawarstwień historycznych posiada, konsekwencją niniejszych warstw są między innymi krzywizny wypraw tynkarskich. Należy pamiętac, ze tynki, ktore byly wykonyane przed elekty ikacja, posiadają naturalne technologiczne struktury, krzywizny, które powstały między innymi w efekcie oświetlenia tynkarzom wnętra świattem migoczącym - świecami, a później lampami naftowymi. Niniejsze przestrzenie najkorzystniej oświetla światto rozproszone, gdyż nie podkreśla ono krzywizn i nierówności, w przeciwieństwie do światła bocznego.

Wnętrza kamienicy mieszkalnej przy ul. Dominikańskiej 3 po modernizacji w latach 2011-2013 zostały zaadaptowane do funkcji hotelowej według projektu Studia S z Krakowa. Pomieszczenia, które pełnią funkcję ogólnie dostępną tj. recep- sacralization, since $1950^{3}$ functioned as a gymnasium. A private investor arranged the "Royal Suite" $\mathrm{m}$ and the height of $11,24 \mathrm{~m}$, was built on an oc$\mathrm{m}$ and the height of $11,24 \mathrm{~m}$, was built on an ocpolychromes featuring ornamental and figural displays from 1920s or 30s in dark shades with gilded elements. The room is lit by five stained glass windows. There are also three rosette windows of a $1.4 \mathrm{~m}$ diameter filled with colored glass and rectangular windows, finished with sectional arch, Window ironwork is located on the wall with the apse and on the side walls, and the once encircled sanctum area. The entire composition was though function.

Despite the relatively large area of the window openings, the room still looks dark, unadapted for original designation is strongly exposed here, also thanks to the masterful use of light-from the space where the altar once stood, casts a dazzling glow.

\section{Artificial lighting desig}

Lighting historical interior with artificial light is a natural process shaped both by contemporary designers and users. Typically, the older the building, the more layers of historical features, the consequence of these layers are among other things, the curvature of the plasterwork. Its worth keeping in mind that the plasterwork done prior to electrification, have a natural technological structure curvature, which created, among other things as a result of the lighting plasterers used; flickering light - candles and oil lamps later. These spaces are preferably illuminated by scattered light, as it light from the side.
lizes and apposed to the

Thes adapted to the features of a hotel according to the Design Studio S. Spaces that are generally available ex., reception, restaurant, bar, have been spot illum nated by sconces in the rustic style (ill. 8 and 9 ). The Communication space was lit by applying longitudimeasuring 2,47 mat 5,95m in the upper part filled with colored glass and bottom with clear glass. through and composed to emphasize is liturgical cja, restauracja, bar, zostały oświetlone punktowo, kinkietami o rustykalnej formie(il 8 i 9 ).

Przestrzeń komunikacyina została oświetlona poprzez zastosowanie podłużnych, gipsowych opraw kinkietowych, kierunkujących oświetlenie wertykalnie $w$ stosunku do geometrii ścian oraz żyrandole w formie białych walców, które iluminuja wnetrza rozproszonymi promieniami.

\section{Oświetlenie naturalne elewac}

Elewacje historycznych budynków mieszkaniowych cechuje rozmaitość formy detalu architektonicznego, podziały kondygnacji niejednokrotnie widoczne są przez gzymsowanie, sztukaterię, czy też podział kolorystyczny. Elewacje budynków zabytkowych były projektowane tak, by wykorzystywac możliwie jak najpełniej światło naturalne. Często używano materiałów wykończeniowych, które miały na celu odbijac promienie słoneczne $w$ kontraście do struktur matowych, $t$. tynku, drewna, kamienia.

Kamienica zlokalizowana przy pl. Inwalidów 6/ ul. Pomorskiej 1/ ul. Sienkiewicza 2-2a jest doskonałym przykładem, w jaki sposób projektanci z okresu XX-lecia międzywojennego wykorzystywali światto naturalne, aby podkreślać i eksponowac elementy architektoniczne oraz prestiż budynku (il. 10).

Kamienica projektu Wactawa Nowakowskiego zostata poddana pracom konserwatorskim w latach 2010-2014 wedłu opracowania pracowni Renowator z Krakowa. Buy wedug p sicil wz w okr zz w okresie powstania ka jacy swatlo elektryczne był juz populanie iwykusze worzace ceglane piony z oknami i wejsciami, oblicowano cegłą poł klinkierową o stosunkowo ciemnej powierzchni spieku. Przestrzennosc wyżej wymienionych elementow podkreslono pasowym wysunięciem co drugiego rzędu wątku, podkreślając tym samym funkcję usługową. Romboidalny pas stanowiący dolną część gzymsu koronuącego również wykonano w wątku ceglanym, ułożonym na gładko $z$ warstw wozówkowych, równolegle do płasz czyzny tynkowanej. Dzięki niniejszemu zabiegowi wydaje się matowy na tle bogatego wystroju. Kolejną cechą, wy różniającą elewację, jest zastosowanie zaprawy tynkarskiej - tynku szlachetnego, barwionego w masie, terabony z mika i łyszczykiem 5 . W strukturze zastosowanego materiału tyn- nal, plaster sconces, which channel light vertically in relation to the geometry of walls and chandeliers in the white cylinders that illuminate the interio with distributed rays.

5. Natural light facad

The facades of historical residential buildings are characterized by a variety of forms of architectura detail, stories often are highlighted by cornices, stuccos, or color division. The facades of historic 作 Ight to it fullest extent. Frequently used materials . trast to matt structures ex. plaster, wood, stone. The house located at pl. Inwalidów 6/ Pomorska street / Sienkiewicza 2-2a street are excellent examples of how the designers from the $X X$ ann versary of the interwar period used natural light to add prestige to the building (Fig. no. 10) Wactaw Nowakowski's tenement house was unaccording to the study of Renovator studio from Cracow. The building has a number of elements that represent facade painting by light of natural origin, although at the time the tenement was built electric light was already in popular use. Both the house side of the building and the bay windows make up the elevations along with the windows and entrances are faced with half-brick with a relaively dark surface of sinter. The area containing the aforementioned elements is emphasized by a band protrusion every second row, the commercial portion is emphasized using the same method. The rhomboidal band which constitutes the lower part of the crown cornice is also made of brid, laid smoothly with layers of stretcher, parallel to the plaster plane. Thanks to this treatment Ans use of plastering morter, fine phaster, the mass is tinted, terrabona with mica 1 In the structure of the plaster material mineral crystals are used that intensely reflect natural light. The building also has a series of elements made of metal. The wooden cornices and rhomboidal shapes were covered with copper plate (ill. 11). The house 


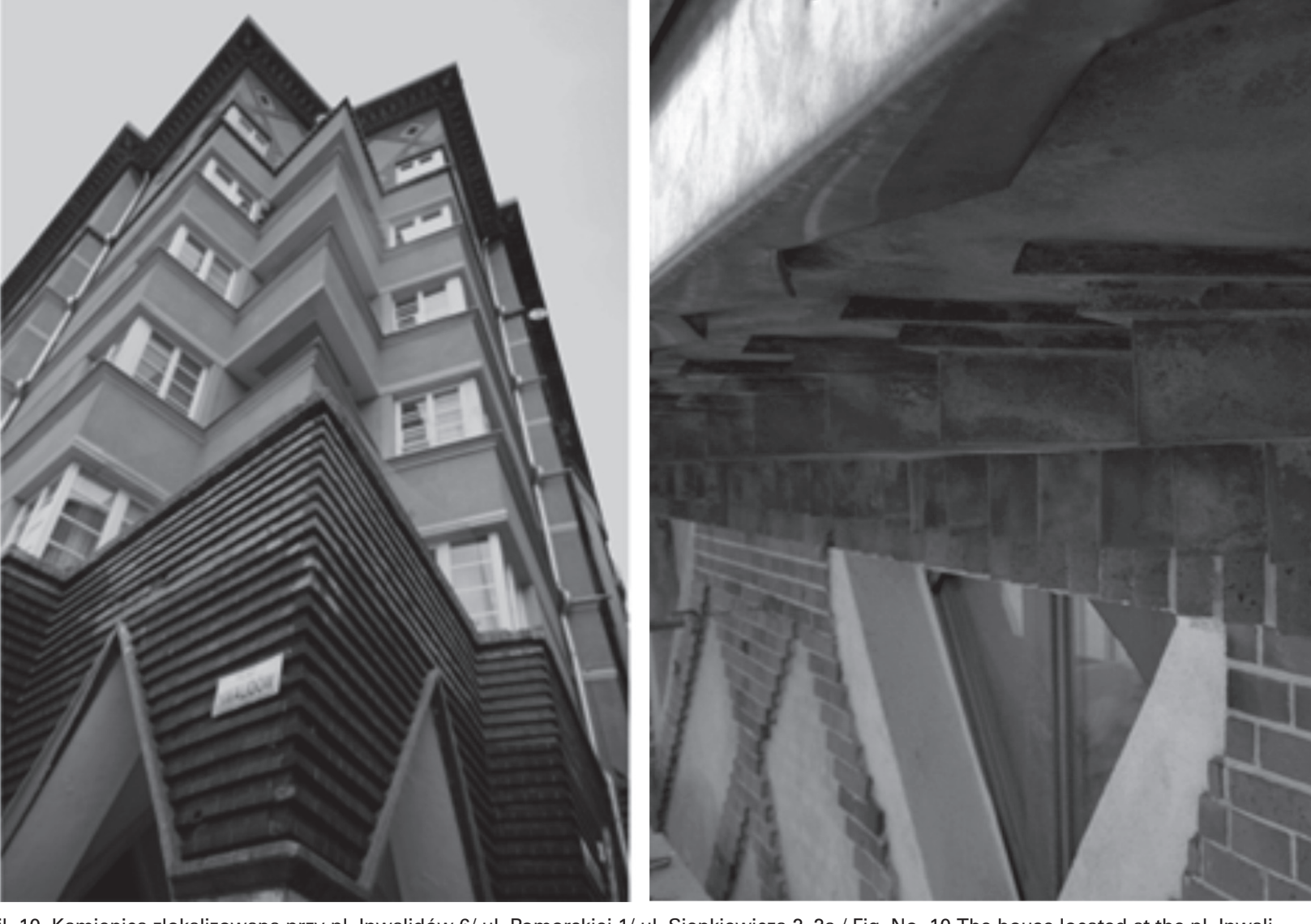

1. 10. Kamienica zlokalizowana przy pl. Invalidów 6/ ul. Pomorskiej 1/ ul. Sienkiewicza 2-2a / Fig. No. 10 The house located at the pl. Inwali-

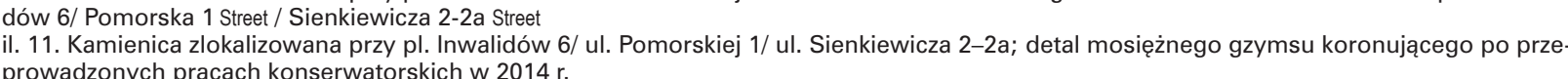

karskiego znajdują się kryształy mineralne, które intensywnie odbijają światło naturalne. Budynek posiada również szereg elementów wykonanych z metalu. Gzyms koronujacy o konstrukcji drewnianej i romboidalnym kształcie został obity blachą miedzianą (il. 11).

Obecnie spowity zielona patyna, stanowi matowy element wystroju, który dzięki barwie kontrastuje z pozostałymi detalami architektonicznymi elwaji. Gzyms zoronujały mi detalakowej formie był błyszczacy, silnie odbija śnjiąto w początNiniejsy zabieg został powtórzony w mniejszej skani w pozioNie pary zion

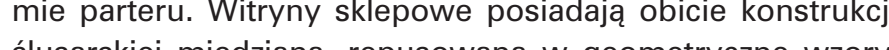
slusarskiej miedzianą, repusowaną w geometryczne wzory, blacha, he mi miala relu, poprez odbijaie slonca, przy ciągac wzrok, lśnic na tle matowej cegly.

Narożny budynek przy ul. św. Tomasza/ ul. Szpitalnej 11 (ii. 12) zaprojektowany został przez Wacława Krzyżanowskiego. Elewacje kamienicy zostaly bogato ozdobione, jednak widoczny jest podział ze względu na funkcję mieszkaniową i usługową. W poziomie usługowego parteru znajduje się szereg drewnianych witryn z metalowymi, miedziany$\mathrm{mi}$, repusowanymi we wzory geometryczne, obramieniam z żaluzjami. Od strony ul. św. Tomasza znajdują się dwa bogato zdobione motywem roślinnym portale wejściowe wykonane ze sztucznego kamienia. Poziom pierwszego piętra został podkreślony przez uzycie gzymsów podkreślonych złotą mozaiką wykonaną z terazzo. Dodatkowo, w poziomie drugiego, trzeciego i czwartego piętra w przestrzeniach międzyokiennych, zlokalizowano kompozycję mozaikową o geometrycznym wzorze w kolorach złota, bieli, czerni i zie- located at the pl. Inwalidów 6/ Pomorska 1 Street I Sienkiewicza 2-2a Street, detail of the brass cornice crown after restoration work was carried out in 2014

Currently shrouded in green patina, is a matt design element, the color contrasts with the other architectural details of the facade. The crown cornice in its initial form was a glossy and strongly reflected sunlight. This treatment was repeated o The shop windows are trimme ground floor. repusoeed with geometric patterns, plating which was designed to reflect the sun, attract the eve, The corner building at Św.Tomasza Street /Szpitalna 11 Street (ill. 12) was designed by Wactaw Krzyżanowski. The building facades are richly decorated, however we can see a division between the residential and commercial portions. In the commercial portion on the ground floor, there is a series of wooden shop windows with metal, copper, repu soeed in geometric patterns, framed with shutters From the Sw. Tomasza street side, it has two portal lloor was highlighted by the use of cornices underdition, at the second, third and fourth floors in spaces in-between the window, we find mosaic artwork made up of geometric pattern in the colors of gold white, black and green. This pattern is located in the central parts of the facade. The remaining window shine some light on a background of dull brick. entryways made of artificial stone, which are richly decorated with floral molis. The level of the first
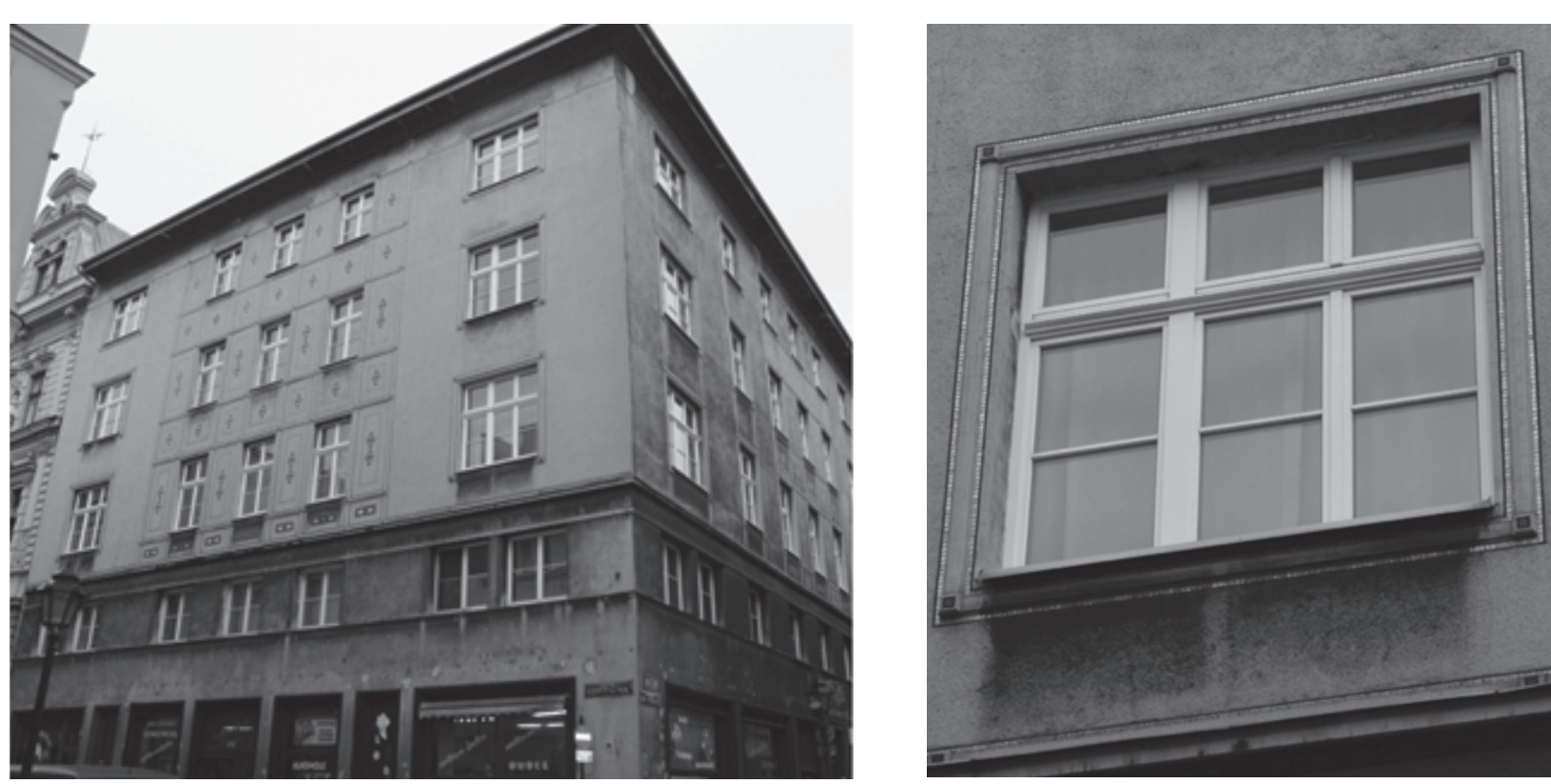

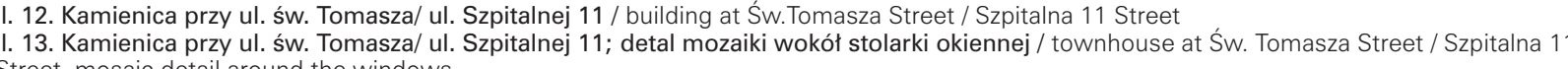

leni. Niniejszy wzór znajduje się $w$ centralnych częściach elewacji. Pozostała stolarka okienna znajdująca się w bocznych partiach elewacji, posiada obramienia okienne również wykonane ze złotego terazzo (il. 13) Cała kompozycja przez kontrast z matowym them wyprawy tynkarskiej, intensywnie Iśni dzięki zastosowanej kolorystyce oraz glazurowanemu wykończeniu.

6. lluminacja elewacji

Historyczna zabudowa mieszkaniowa, dzięki lokalizacji oraz pięknu detalu architektonicznego, stała się pewnego rodzaju synonimem wysokiego statusu społecznego właścicieli poszczególnych lokali oraz całych budynków. Są to oczywiście dwie podstawowe cechy, które determinuja współczesne trendy wyboru nieruchomości przez użytkowników. Aby jeszrene bardziej podkreślić renome miejsca oraz wyróżnić budycze bardziej podkric re nek na tle sassiedniej zabudowy inwestorzy stosują rozmaite oświetlenie punktowe z poziomu posadzki, listwy oświetleniowe mocowane do
gzymsów, kinkiety mocowane do elewacji, itp.

ompleks budynków pod nazwą „Browar Lubicz”, zlokalizowany przy ul. Lubicz i ul. Strzeleckiej, posiada w swojej strukturze zabudowe zabytkowa, która została poddana pracom konserwatorskim w latach 2010-2016. Przestrzeń pozbawioną zabudowy uzupełniono nowoczesną architektura wytwarzając jednocześnie wnetrza konkretne ${ }^{6}$, o charakteze półprywatnym. Zarówno nowe budynki, jak i elementy zabytkowe zostały wyeksponowane przez podświetlenie. Opracowanie projektowe wykonał zespół Mofo Architekc z Krakowa.

Wykonano iluminację zabytkowych elewacji, nowo wybudowanej zabudowy, przestrzeni komunikacyjnych i pla- joinery in the lateral parts of the facade has framing composition through its contrast with the plastercation of colors and glazed finish.

\section{Illumination of the elevation}

Historical residential buildings, thanks to their location and beauty of the architectural details, have be of individual dwellings and buildings. These are of rent trends in property selection by users. In order 作 the backgroun ung casteint lighting nice, wall mounted sconces, etc.

The complex of buildings named "Browar Lubicz", located at Lubicz street and Strzelecka street has in its structure historic buildings, which have undergone restoration works in the years 2010-2016. by modern architecture, while producing substantial semi-private interior 6 . Both new huildings and historic elements had been highlighted by lighting. The project was designed by Mofo Architects from

llumination work has been done for historic facades, newly built buildings, communication spaces and squares between buildings. Severa types of lighting elements have been utilized, such the floor tiles for city squares, spot lights with elemade from golden terrazzo (Fig. no. 13). The whole come a synonym of the high social status of owners course two basic features that determine the curfrom the floor level, light fixtures affixed to the cor- 


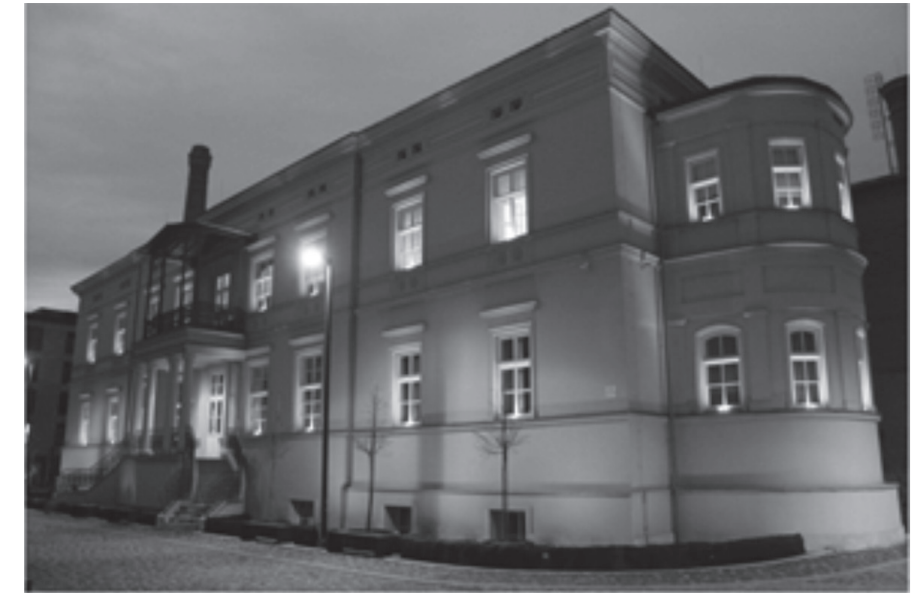

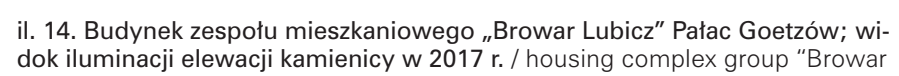
Lubicz" Palac Goetzón view of the facade illumination in the 2017

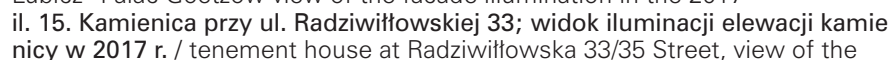
nicy $w 2017 \mathrm{r} / \mathrm{f}$ enement house at
illumination of

ców pomiędzy zabudową. Zastosowano szereg elementów oświetleniowych, takich jak oprawy z zastosowaniem diod elektroluminescencyjnych w posadzce placów, oświetlenie punktowe przy elementach stolarki okiennej i wejściu do $\mathrm{Pa}$ łacu Goetzów (il. 14), lampy o charakterze ulicznym ze świattem ukierunkowanym pod kątem ok. $45^{\circ} \mathrm{W}$ stronę terenu, czy też oświetlenie słupowe typu ulicznego. Ponadto, całą przestrzeń doświetlają intensywnie lokale usługowe zlokalizowane w parterach

Narożna kamienica zlokalizowana przy ul. Radziwiłłowskiej 33/35 zaprojektowana przez Karola Scharocha ${ }^{7}$, została wybudowana w latach 1899-1902 przez rodzinę Machaufów. Remont budynku został wykonany w 2009 roku, w oparciu o projekt wykonany przez Pracownie Projektowania Architektonicznego z Krakowa. Projekt remontu kamienicy zaktada intensywna iluming ter o funkci ustugowej nie posia wyraźnego zazny parpoprzez dodatkowe oświetlenie. Kolejne kondygnacje mają poprzez dodatkowe oswie te

Poszczególne piętra zostały podkreślone liniowym oświetlePoszczegóne pięra zostaly podkreslone Iniowym oswietleniem, kóre w poziomach pierwszego i trzeciego piętra, zostalo ulożon wozio ono bogata dekorace obramien okiennych w formie aediculi, piedestały pilastrow ozdobione sztukaterią $\mathrm{w}$ formie wieńców laurowych w poziomie pierwszego piętra, sztukateryjne festony, maszkarony oraz motywy muszlowe. W poziomie drugiego piętra oprawy oświetleniowe umieszczono równo z poziomem parapetow okiennych, tworząc tym samym iluzję gzymsu. Poddasze użytkowe z lukarnami oświetlono w sposób flankujący. Dzięki temu ograniczono oswietlenie wnętrz w nocy. Naroże kamienicy zwieńczone cebulastą kopułą, iluminowano liniowo ułożonymi oprawami, które akcentuja zmianę geometrii zabudowy.

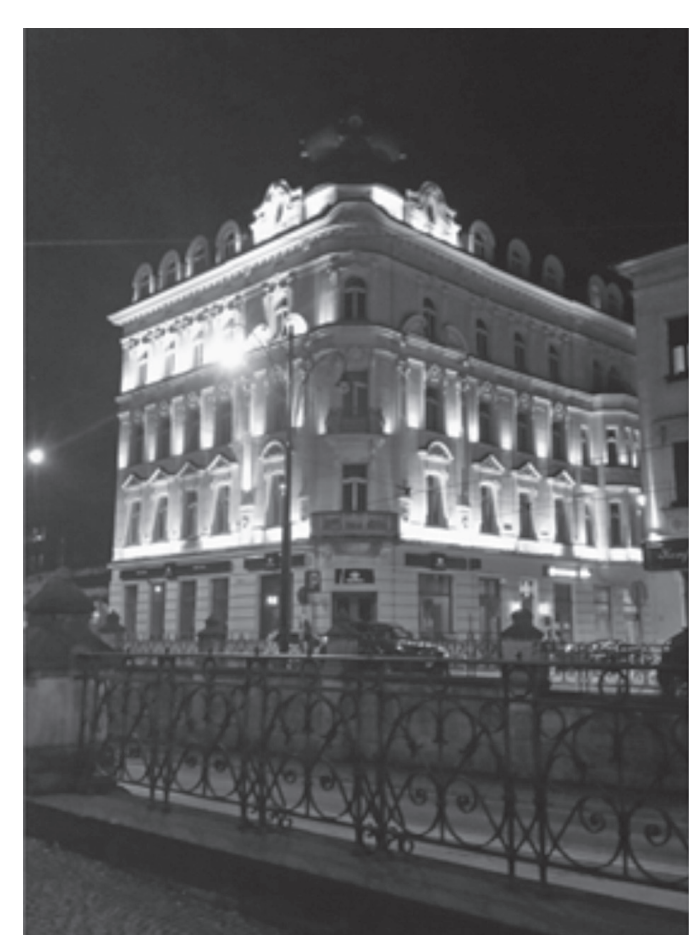

ments of window woodwork and at the entrance to the Patac Goetzów (ill. 14), street lamps with the light focused at $45^{*}$ in the direction terrain, or the light pillar type street lighting. In addition, the entre space is intensely light by the commercial

The con $33 / 35$ 1899-1902 by the Machauf family. This building was renovated in 2009, based on the design Pracowni Projektowania Architektonicznego from Cracow. The renovation project of the tenement house proposed intensive illumination of the front elevations. A rustic design ground floor with a commercial character that is not clear defined through additional lighting. The next floor has a residential character (ill. 15).

Each floor was highlighted by linear lighting, which in the first and the third floors was arranged paralel to the cornice. It highlights and enhances the rich decoration of the window frames in the form of aedicule, pedestals, and pilasters adorned with stucco in the form of laurel wreaths on the level of the first floor, stucco festoons, mascots and shell motifs. At the level of the second floor, the light fixforming the illusion of a cornice. Attic is flanked with floodlights. This has reduced the lighting of the interiors at night The corner of the building topped with an onion dome, illuminated with linear light fixtures that accentuate the change in the geometry of the building

Elevation at Topolowa 8 Street is an example of the illumination of the facade of a tenement house. The building has a seven-sided front facade, whose renovation was carried out according to a design

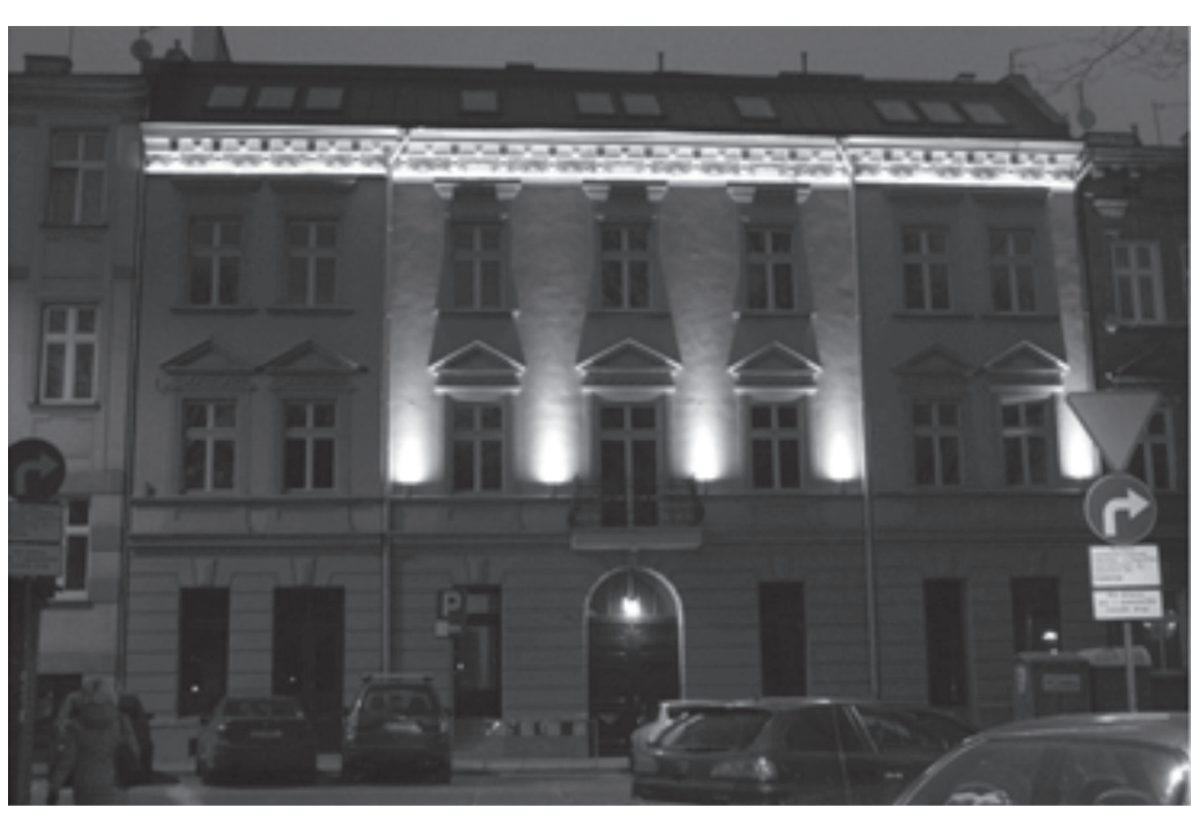

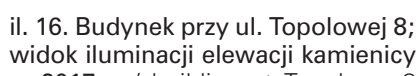
W 2017 r. / building at Topolowa 8
Street, view of the illumination of the

Elewacja przy ul. Topolowej 8 jest przykładem iluminacji fasady kamienicy mieszkalnej. Budynek posiada siedmioosiowa elewację frontową, której remont konserwatorski przeprowadzono według projektu autorstwa Maak Studio z Krakowa $w$ latach 2014-2016. Elewacja frontowa budynku została podświetlona oprawami w formie walców zlokalizowanymi w poziomie pierwszego piętra, nad gzymsem (il. 16).

Zastosowane oświetlenie ukierunkowano równolegle do płaszczyzn tynkowych elewacji, przez co uzyskano w tym miejscu tzw. oświetlenie boczne. Niniejsza lokalizacja punktów świetlnych spowodowała ograniczenie doświetlenia wnętrza w porach nocnych jednak uwydatniła tym samym wszelkie niedoskonałości oraz krzywizny pozornie płaskiego elementu. Bogato zdobiony gzyms koronujący podświetlono liniowo i równomiernie, przez co uzyskano mocny akcent zwieńczający całą elewację

\section{Podsumowanie}

światło naturalne jest elementem ekosystemu, właściwym dla ksztattowania przestrzeni mieszkaniowej. Od wieków determinowało formę zabudowy, począwszy od starożytności, kiedy wykorzystywano układ słońca względem zabudowy, poprzez symboliczne wykorzystanie do podkreślenia strefy sacrum, po czasy wspótczesne.

Jak powiedział Le Corbusier Architektura jest mądrą, skoor dynowaną grą brył w świetle. Determinowało ono również usytuowanie budynków oraz funkcję poszczególnych wnętrz w budownictwie mieszkaniowym. Warto dodać, że właściwe oświetlenie wnętrza świattem pochodzenia naturalnego wpływa korzystnie przez gospodarkę hormonalną na zdrowie użytkowników ${ }^{8}$.

Współczesne podejście do eksponowania zabytku przewiduje szereg zabiegów, które mają na celu podniesienie atrakcyjnosci komercyjnej przestrzeni, komfortu oraz bezpieczeństw użytkowników. Dzięki postępowi technologicznemu coraz więcej inwestorów decyduje się na wykonanie iluminacji hi- by Maak Studio from Cracow in 2014-2016. The font facade of the building was illuminated with above the cornice (ill 16).

ghting applied was directed parallel to the planes of the facade, thereby creating side lighting. illumination of the interior during nighttime the has highlighted all the imperfections and curves of the apparently flat element. The richly decorated cornice which was illuminated linearly and evenly, resulting in a strong accent encompassing the entire facade.

\section{Summary}

Natural light is a component of an ecosystem that is approprite for the shaping of a living space. For centuries it has determined the form of a building since antiquity, when the position of the sun relative to the building, or for symbolic use to emphasize a sacred space, up to modern times.

As Le Corbusier said "Architecture is a wise, coordinated game of lumps in the light". It also deter-

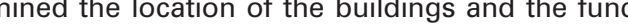
mion or individual interiors in housing construction. tis worth adding that proper lighting of the interior with light of natural origin is beneficial for health of its users.

Contemporary approaches to exhibiting the historical buildings provide a number of treatments imed at enhancing the attractiveness of commercial space, comfort and safety of users. Thanks to ere opting for the illumination of historic factors In this way, they try to increase the attractiveness of the investment and its prestige. Often, however it is forgotten that the vast majority of historic buildings were not originaly planned considering the use artificial light. For this reason, the introducing of a foreign element in too intensely can distort 
storycznych fasad. W ten oto sposób próbuje się podnieść atrakcyjność inwestycji oraz jej prestiż. Często jednak zapomina się o fakcie, iż zdecydowana większość budynków zabytkowych nie została pierwotnie przemyślana pod kątem wykorzystania światła pochodzenia sztucznego. Z tego powodu wprowadzenie elementu obcego w zbyt dużym natężeniu może zaburzyć odbiór historycznych struktur. Istnieją jednak przykłady, gdzie w sposób świadomy i konsekwentny dobrano sposób iluminacji budynku wydobywając tym samym subtelne detale architektoniczne.

\section{PRZYPISY:}

1 M.Twarowski, Słońce w architekturze, Arkady, Warszawa 1960

2 Rozporządzenie Ministra Infrastrukturyz dnia 12.04. 2002 r. (...) wraz z aktualizacja z dnia 01.01.2014r. (Dz.U. Nr 75, poz. 690)

3 W. Niewalda, Program prac konserwatorskich, mps, Kraków 2004, s. 54. ${ }^{4}$ W. Niewalda, Program prac konserwatorskich, mps, Kraków 2004, s. 25, $51-$ 52.

${ }^{5}$ R. Wojciechowski, Program prac konserwatorskich, Maszynopis, Kraków 2009, s. 43.

${ }^{6}$ J.Bogdanowski, Metoda jednostek i wnętrz architektoniczno-krajobrazowych (JARK-WAK) w studiach i projektowaniu, (podstawowe wiadomości), pomoc dydaktyczna,Wyd. 2. Politechnika Krakowska, Kraków 1990

7 APKr, zespół Akt Budownictwa Miejskiego, sygn. ul. Lubicz 7 dok. 20 z 10 VIII 1899

${ }^{8}$ Z.Turlej, E.Lisak, Czynnik hormonalny w oświetleniu wnętrza, Prace Instytutu Elektrotechniki, zeszyt 228, Warszawa 2006

\section{LITERATURA:}

Bartnicka M., Wczoraj, dziś i jutro w promieniach słonecznych (?), Wydawnictwo Politechniki Krakowskiej, Kraków 2010.

Bogdanowski J., Metoda jednostek i wnętrz architektoniczno-krajobrazowych (JARK-WAK) w studiach i projektowaniu, (podstawowe wiadomości), pomoc dydaktyczna, Wyd. 2. Politechnika Krakowska, Kraków 1990.

Krupiński R., Dwie drogi projektowania iluminacji obiektów, Przegląd Elektrotechniczny, r. 91, nr 4/2015, Warszawa 2015.

Mączyński D., Iluminacje zabytków - w poszukiwaniu kryteriów oceny, Wiadomości Konserwatorskie 20/2006, Warszawa 2006.

Niewalda W., Program prac konserwatorskich, mps, Kraków 2004

Rozporządzenie Ministra Infrastruktury z dnia 12. 04. 2002 r. (...) wraz z aktualizacją z dnia 01.01.2014r. (Dz.U. Nr 75, poz. 690).

Sulma M., Kaczorowska M.K., Czas na teorię?, Ochrona Zabytków nr 3-4, 2003. Turlej Z., Lisak E., Czynnik hormonalny w oświetleniu wnętrza, Prace Instytutu Elektrotechniki, zeszyt 228, Warszawa 2006

Turlej Z., Narzędzia projektowania oświetlenia dziennego w budynkach, Prace Instytutu Elektrotechniki, zeszyt 256, Warszawa 2012

Twarowski M., Stońce w architekturze, Arkady, Warszawa 1960.

Witwicki M., Aktualne problemy iluminacji obiektów zabytkowych, Wiadomości Konserwatorskie 20/2006. Warszawa 2006.

Wojciechowski R., Program prac konserwatorskich, mps, Kraków 2009. the reception of historical structures. However, there are examples in which the method of illumination of a building has been consciously and consistently carried out, thus extracting subtle architectural details.

\section{ENDNOTES:}

${ }^{1}$ M.Twarowski, Słońce $w$ architekturze, Arkady, Warsaw 1960 2 Rozporzadzenie Ministra Infrastrukturyz dnia 12.04. 2002 r. (...) wraz z aktualizacją z dnia 01.01.2014r. (Dz.U. Nr 75, poz. 690)

${ }^{3}$ W. Niewalda, Program prac konserwatorskich, mps, Cracow 2004, s. 54

4 W. Niewalda, Program prac konserwatorskich, mps, Cracow 2004, s. 25, 51-52.

${ }^{6} \mathrm{~J}$.Bogdanowski, Metoda jednostek i wnętrz architektoniczno-krajobrazowych (JARK-WAK) w studiach i projektowaniu, (podstawowe wiadomości), pomoc dydaktyczna, Wyd. 2. Politechnika Krakowska, Cracow 1990

${ }^{7}$ APKr, zespół Akt Budownictwa Miejskiego, sygn. ul. Lubicz 7 dok. 20 z 10 VIII 1899.

8 Z.Turlej, E.Lisak, Czynnik hormonalny w oświetleniu wnętrza, Prace Instytutu Elektrotechniki, zeszyt 228, Warsaw 2006.

\section{BIBLIOGRAPHY:}

Bartnicka M., Wczoraj, dziś i jutro w promieniach słonecznych (?), Wydawnictwo Politechniki Krakowskiej, Kraków 2010. Bogdanowski J., Metoda jednostek i wnętrz architektoniczno-krajobrazowych (JARK-WAK) w studiach i projektowaniu, (podstawowe wiadomości), pomoc dydaktyczna, Wyd. 2. Politechnika Krakowska, Kraków 1990.

Krupiński R., Dwie drogi projektowania iluminacji obiektów. Przegląd Elektrotechniczny, r. 91, nr 4/2015, Warszawa 2015.

Mączyński D., Iluminacje zabytków - w poszukiwaniu kryteriów oceny, Wiadomości Konserwatorskie 20/2006, Warszawa 2006.

Niewalda W., Program prac konserwatorskich, mps, Kraków 2004.

Rozporządzenie Ministra Infrastruktury z dnia 12. 04. 2002 r. (...) wraz z aktualizacją z dnia 01.01.2014r. (Dz.U. Nr 75, poz. 690).

Sulma M., Kaczorowska M.K., Czas na teorię?, Ochrona Zabytków nr 3-4, 2003

Turlej Z., Lisak E., Czynnik hormonalny w oświetleniu wnętrza Prace Instytutu Elektrotechniki, zeszyt 228, Warszawa 2006. Turlej Z., Narzedzia projektowania oświetlenia dziennego w budynkach, Prace Instytutu Elektrotechniki, zeszyt 256, Warszawa 2012.

Twarowski M., Stońce w architekturze, Arkady, Warszawa 1960.

Witwicki M., Aktualne problemy iluminacji obiektów zabytkowych, Wiadomości Konserwatorskie 20/2006, Warszawa 2006.

Wojciechowski R., Program prac konserwatorskich, mps, Kraków 2009.

All photographs was taken by the author 